\title{
Higher Incidence of Lung Adenocarcinomas Induced by DMBA in Connexin 43 Heterozygous Knockout Mice
}

\author{
Krishna Duro de Oliveira, Marcello Vannucci Tedardi, \\ Bruno Cogliati, and Maria Lúcia Zaidan Dagli \\ Department of Pathology, School of Veterinary Medicine and Animal Science, University of São Paulo, \\ Avenue Professor Dr. Orlando Marques de Paiva 87, 05508-900 Sao Paulo, SP, Brazil \\ Correspondence should be addressed to Maria Lúcia Zaidan Dagli; mlzdagli@yahoo.com.br
}

Received 22 March 2013; Accepted 8 August 2013

Academic Editor: Sircili MP

Copyright (C) 2013 Krishna Duro de Oliveira et al. This is an open access article distributed under the Creative Commons Attribution License, which permits unrestricted use, distribution, and reproduction in any medium, provided the original work is properly cited.

\begin{abstract}
Gap junctions are communicating junctions which are important for tissue homeostasis, and their disruption is involved in carcinogenic processes. This study aimed to verify the influence of deletion of one allele of the Connexin 43 gene on cancer incidence in different organs. The 7, 12-dimethylbenzanthracene (DMBA) carcinogenic model, using hebdomadary doses by gavage of $9 \mathrm{mg}$ per animal, was used to induce tumors in Connexin 43 heterozygous or wild-type mice. The experiment began in the eighth week of the mice life, and all of them were euthanized when reaching inadequate physical condition, or at the end of 53 weeks. No statistical differences occurred for weight gain and cancer survival time $(P=0.9853)$ between heterozygous and wild-type mice. $\mathrm{Cx} 43^{+/-}$mice presented significantly higher susceptibility to lung cancer $(P=0.0200)$ which was not evidenced for benign neoplasms $(P=0.3449)$. In addition, incidence of ovarian neoplasms was 2.5 -fold higher in $C \times 43^{+/-}$mice, although not statistically significant. Other organs showed a very similar cancer occurrence between $\mathrm{Cx} 43$ groups. The experiment strengthens the evidence of the relationship between Connexin 43 deficiency and carcinogenesis.
\end{abstract}

\section{Introduction}

Gap junction, first described in the beginning of the 1960's [1], is a cell membrane junction responsible for cell-tocell communication, being one of the mechanisms involved in tissue homeostasis, proliferation, and differentiation [25]. Connexins are the basic units of these junctions, being expressed by 21 genes in human and 20 in mice [6]. The union of 6 of these proteins is responsible to form a connexon, a hemichannel structure normally allocated in cell membrane $[5,7,8]$. When connexons from neighbor cells connect, they allow the interchange of substances with 1,000 Da or less, like water, ions, sugars, small peptides, amino acids, fatty acids, and drugs $[5,9]$.

Cell growth, proliferation, and apoptosis are regulatory mechanisms shared between cells, and any disruption of this process may allow the development of many disorders. Cell-to-cell communication pathway has been studied to better understand inflammatory, regenerative, and oncogenic processes $[3,7,10]$. A considerable number of studies after the classic Loewenstein and Kanno [11] publication have shown the correlation between the lower communication capacity and the development of cancer.

This study has been performed in order to verify if the heterologous deletion of one allele of $\mathrm{Cx} 43$ could contribute to enhance the incidence of different cancers in mice, when compared to wild-type mice. DMBA carcinogenesis was the model of choice, based on previously conducted experiment, where breast, lung, skin, lymphoid, digestive tract, and ovary cancers were evidenced [12].

\section{Materials and Methods}

2.1. Animals. The heterozygous knockout mice for Connexin $43\left(\mathrm{Cx} 43^{+/-}\right)$were generated by replacing exon- 2 of the $\mathrm{Cx} 43$ gene by neomycin resistance gene [13]. This animal model was used because Connexin 43 knockout mice $\left(\mathrm{Cx} 43^{-/-}\right)$ 
die after birth due to cardiac congenital abnormalities [13]. Animals were kindly provided by International Agency for Research on Cancer (IARC, Lyon, France) and originally were produced in the $\mathrm{C} 57 \mathrm{BL} / 6$ strain. Their background was subsequently changed to CD1 by serial breeding at the IARC. The Cx43 expression was characterized by real-time polymerase chain reaction (PCR) and Western blot in these $\mathrm{Cx} 43^{+/-}$mice, showing reduced mRNA amount and lower Cx43 levels than wild types according to previouse studies from our group [14]. 155 female mice wild-type $\left(\mathrm{Cx} 43^{+/+}\right)$and heterozygote $\left(\mathrm{Cx} 43^{+/-}\right)$mice were randomly provided by the Animal Facility of the Department of Pathology, School of Veterinary Medicine and Animal Science of the University of São Paulo. The experiment was blind; the authors were not informed if animals were wild types or heterozygotes during the mice life time, necropsy, and histopathology procedures. Only female mice were used to favor breast cancer development.

The animals were kept in a room with ventilation (1618 air changes/hour), relative humidity (45-65\%), controlled temperature $\left(20-24^{\circ} \mathrm{C}\right)$, and light/dark cycle 12:12 and were given water and balanced diet ad libitum. The study has been approved by the Committee on Bioethics of the School of Veterinary Medicine and Animal Science of the University of São Paulo, Proc. no. 1876/2010.

2.2. Carcinogenesis. Carcinogenesis was induced by $\mathrm{f} 7,12-$ dimethylbenzanthracene (Sigma), diluted in corn oil and administered by gavage [12]. Each animal received $1 \mathrm{mg}$ per week until completing the total dose of $9 \mathrm{mg}$. Control group was composed of 20 mice, receiving only corn oil, also by gavage. Animals were weighted and received careful clinical examination weekly. The experiment began in the eighth week of life of animals, and all animals were euthanized when reaching inadequate physical condition, or at the end of 53 weeks.

2.3. Necropsy and Histopathology Study of Tumors. Necropsy was performed in all animals of the experiment, and tumors, mammary glands, gastrointestinal tract, liver, spleen, heart, lung and kidneys were collected and fixed in 10\% formaldehyde solution. All mouse tumors were classified according to IARC Scientific Publication no. 111 [15].

2.4. Genotyping. DNA from each mouse was obtained from tail biopsies. Mice were genotyped for Connexin 43 gene by polymerase chain reaction (PCR) as described by Yamakage and collaborators (1998) [16]. The primers were used in respect to the following sequence: CCCACTCTCACCTATGTCTCC- $3^{\prime}$ and antisense $5^{\prime}$-ACTTTTGCCGCCTAGCTATCCC- $3^{\prime}$ observed at 520 bp; neo-sense $5^{\prime}$-GGCCACA GTCGATGAATCCAG-3' and antisense $5^{\prime}$ TATCCATCATGGCTGATGCAA-3' observed at 294 bp.

2.5. Statistical Analysis. Statistical analysis was performed using the GraphPad Prism (version 5.0, GraphPad Software Inc., USA). Chi-square test and Fisher's exact test were used

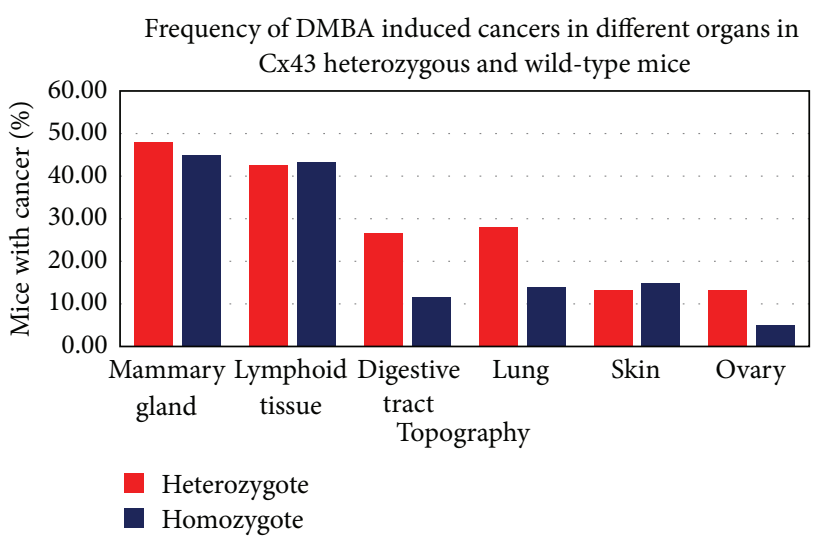

FIGURE 1: Bar graphic showing the proportional incidence among different topographies compared with the $\mathrm{Cx} 43^{+/-}$and $\mathrm{Cx} 43^{+/+}$ groups.

to compare incidence between both $\mathrm{Cx} 43^{+/-}$and $\mathrm{Cx} 43^{+/+}$ groups. Odds ratio and relative risk and descriptive studies of the mean of tumors per animal in each group were also assessed. Logrank test was performed in order to evaluate the survival difference between $\mathrm{Cx} 43^{+/+}$and $\mathrm{Cx} 43^{+/-}$mice. The significance level was set at $P<0.05$.

\section{Results}

Control group after genotype was composed of 10 homozygote animals (wild types) and 10 heterozygous animals for $\mathrm{Cx} 43$, and none of them developed any type of neoplasia. 135 mice that received DMBA after genotype were divided in two groups, composed of 60 wild-type mice and $75 \mathrm{Cx} 43$ heterozygous mice.

Neoplasms began to appear in the 8th week after DMBA injection and affected $100 \%$ of DMBA treated mice.

No significant statistical differences were observed in weight gain and survival time $(P=0.9853)$ between $\mathrm{C} \times 43^{+/-}$and $\mathrm{Cx} 43^{+/+}$DMBA induced groups (data not shown). Incidence rate of neoplasms in different organs and the histopathological classification of the neoplasms are presented in Table 1 and Figure 1.

Chi-square test and Fisher's Exact test were performed to the observe difference in incidence of cancers in different locations between $\mathrm{Cx} 43^{+/-}$and $\mathrm{Cx} 43^{+/+}$DMBA induced groups.

It has been detected a statistically significant difference in the incidence of lung adenocarcinomas, where $\mathrm{Cx} 43^{+/-}$ mice presented a 1.4-fold higher risk than wild-type animals (Table 2). Histopathology images of lung cancer are presented in Figure 2.

Benign lung neoplasia was diagnosed in 8 and 3 animals from $\mathrm{Cx} 43^{+/-}$and $\mathrm{Cx} 43^{+/+}$DMBA treated animals, respectively. The relative risk for developing papillary lung adenoma in heterozygous group, when compared with wildtype animals, was 2.133 (IC 95\% 0.5913-7.696), and odds ratio were 2.269 (IC 95\% 0.5745-8.959). The $P$ value was 0.3449 for Fisher's Exact Test, and therefore, there was no difference 
TABLE 1: DMBA induced cancer incidence in $\mathrm{Cx} 43^{+/-}$and $\mathrm{Cx} 43^{+/+}$mice divided by topography and tumor histopathological classification.

\begin{tabular}{|c|c|c|c|c|}
\hline \multirow{2}{*}{ Cancer } & \multicolumn{2}{|c|}{$\mathrm{Cx} 43^{+/-}(n=75)$} & \multicolumn{2}{|c|}{$\mathrm{Cx} 43^{+/+}(n=60)$} \\
\hline & Number of tumors & $\%$ & Number of tumors & $\%$ \\
\hline Mammary gland & $n=36$ & 48.00 & $n=27$ & 45.00 \\
\hline Adenoacanthoma & 20 & 47.62 & 10 & 34.48 \\
\hline Adenocarcinoma type A & 5 & 11.90 & 4 & 13.79 \\
\hline Adenocarcinoma type C & 1 & 2.38 & 0 & 0.00 \\
\hline Carcinosarcoma & 0 & 0.00 & 0 & 0.00 \\
\hline Cystic adenocarcinoma & 12 & 28.57 & 12 & 41.38 \\
\hline Fibrosarcoma & 1 & 2.38 & 0 & 0.00 \\
\hline undifferentiated type & 1 & 2.38 & 0 & 0.00 \\
\hline Organoid & 2 & 4.76 & 0 & 0.00 \\
\hline Total & 42 & 100.00 & 29 & 100.00 \\
\hline Digestive tract & $n=20$ & 26.67 & $n=16$ & 26.67 \\
\hline Squamous cell carcinoma & 20 & 95.24 & 16 & 5.52 \\
\hline Gastric adenocarcinoma & 1 & 47.61 & 0 & 0.00 \\
\hline Total & 21 & 100.00 & 16 & 100.00 \\
\hline Lymphoid tissue & $n=32$ & 42.67 & $n=26$ & 43.33 \\
\hline Lymphoma & 32 & 100.00 & 26 & 100.00 \\
\hline Total & 32 & 100.00 & 26 & 100.00 \\
\hline Skin & $n=10$ & 13.33 & $n=9$ & 15.00 \\
\hline Squamous cell carcinoma & 10 & 100.00 & 9 & 100.00 \\
\hline Total & 10 & 100.00 & 9 & 100.00 \\
\hline Lung & $n=21$ & 28.00 & $n=7$ & 11.66 \\
\hline Papillary adenocarcinoma & 21 & 95.45 & 7 & 100.00 \\
\hline Bronchial carcinoma & 1 & 4.45 & 0 & 0.00 \\
\hline Total & 22 & 100.00 & 7 & 100.00 \\
\hline Ovary & $n=10$ & 13.33 & $n=3$ & 5.00 \\
\hline Granulosa cell carcinoma & 10 & 100.00 & 3 & 100.00 \\
\hline Total & 10 & 100.00 & 3 & 100.00 \\
\hline Total & 137 & & 90 & \\
\hline Number of cancer histological types per animal & 1.83 & & 1.50 & \\
\hline
\end{tabular}

Note: there are more tumors than mice in the experiment because some animals developed more than one type of cancer in the same or different organs.

in the incidence of lung papillary adenomas in $\mathrm{Cx} 43^{+/-}$and $\mathrm{Cx} 43^{+/+}$mice.

\section{Discussion}

The aim of this study was to verify if the deficiency in Connexin 43 could increase the susceptibility to different types of neoplasms in mice. For this purpose, the DMBA carcinogenesis model was used, since it has previously been shown, in BALB/c mice, that this carcinogen induces not only mammary tumors but also lung, digestory, lymphoid, and other neoplasms [12].

The $100 \%$ of cancer occurrence in DMBA induced mice in this study is in accordance with the incidence rate of cancers in the study presented by Tedardi et al. [12]. The purpose was to investigate possible correlations of the deletion of one $\mathrm{Cx} 43$ allele on cancer development in different organs.
The statistical analysis demonstrated a higher incidence of lung cancer in $\mathrm{Cx} 43^{+/-}$mice when compared to wild-type animals.

Gap junctions are known to be involved in lung carcinogenesis. This information can be clearly demonstrated by Cesen-Cummings et al. study [17]. They cultivated human and mouse cell lines of normal and neoplastic lung tissues and compared the cell-to-cell transfer of Lucifer Yellow coupling dye, observing a higher dye transfer in nonaffected tissue than in cancerous ones (represented by lung small cell carcinoma, squamous cell carcinoma, adenocarcinoma and large cell carcinoma in human cell lines and carcinoma in mouse cell line) [17]. Coculturing the normal and cancer cells, they still noted the lower capacity of neoplastic cells to communicate with each other and with normal cells [17].

Several studies evidenced the correlation of $\mathrm{Cx} 43$ expression in lung carcinogenesis. Human and mouse lung cancer 


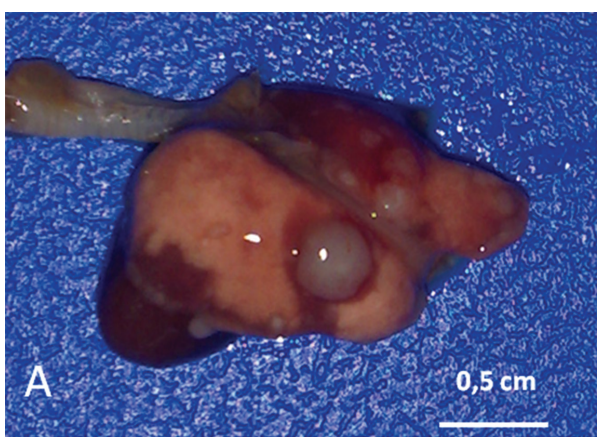

(a)

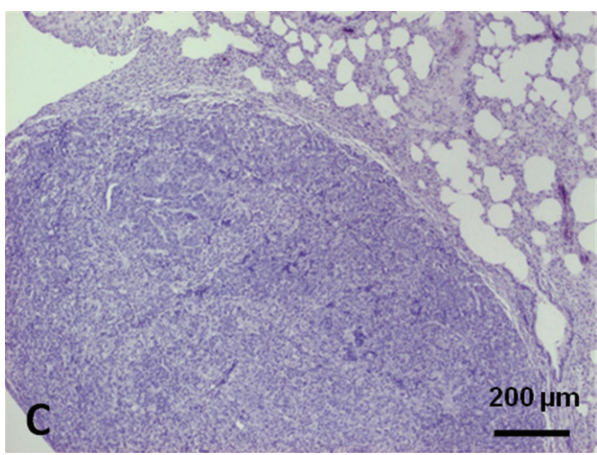

(c)

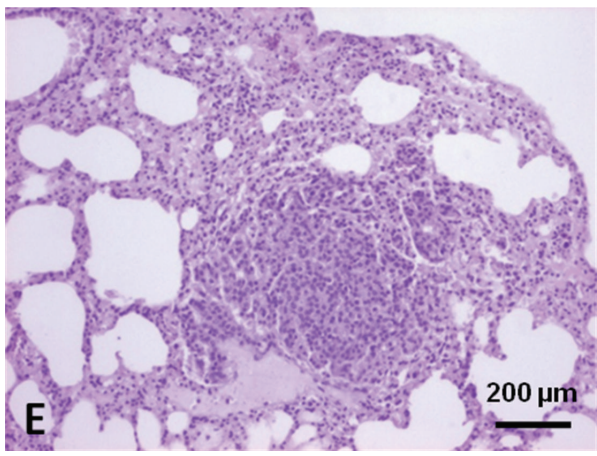

(e)

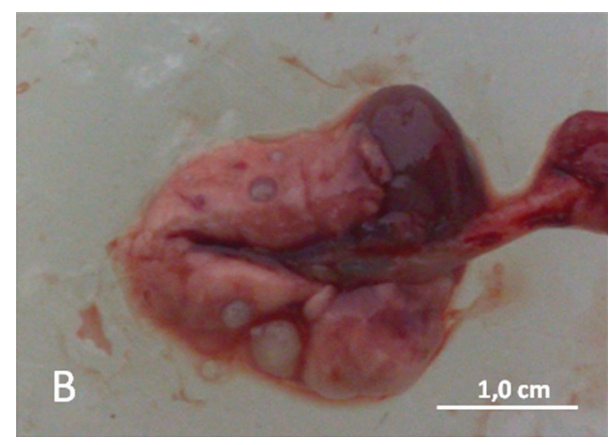

(b)

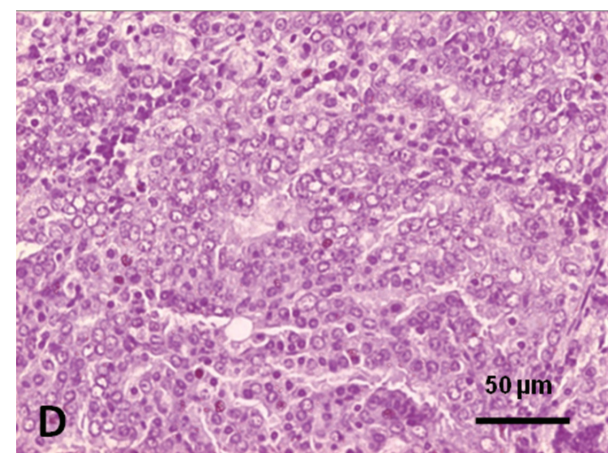

(d)

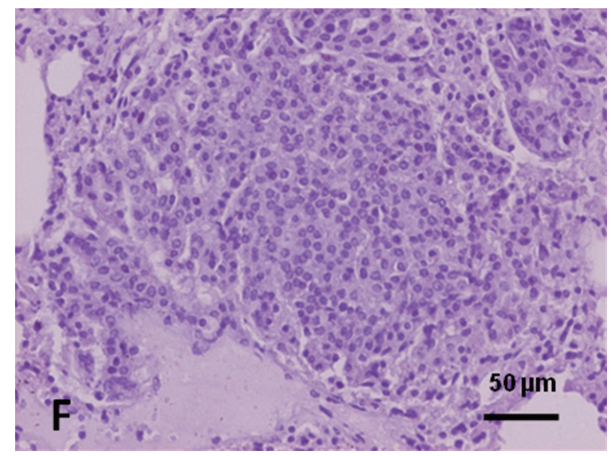

(f)

Figure 2: (a) Gross picture of $\mathrm{Cx} 43^{+/-}$mouse lung, showing gray nodules of $0.1-0.3 \mathrm{~cm}$ of diameter. (b) Gross picture of $\mathrm{Cx} 43^{+/+} \mathrm{mouse}$ lung, showing red and grey nodules of $0.3 \mathrm{~cm}$ or less of diameter. Bar $=0,5 \mathrm{~cm}$, and bar $=1,0 \mathrm{~cm}$. (c) and (d). Lung bronchial carcinoma, $\mathrm{H} \& \mathrm{E}$, bar $=200 \mu \mathrm{m}$, and bar $=50 \mu \mathrm{m}$. (e) and (f). Lung with solid papillary adenomas, H\&E, $200 \mu \mathrm{m}$, and $50 \mu \mathrm{m}$.

cell lines had a lower expression of connexin 43 by Western blot and Southern blot analysis [17] and immunohistochemistry. In a study with 107 samples of human lung cancers, it has been shown a decrease in numbers of $\mathrm{Cx} 43$ spots and loose of membrane stain with replacement by cytoplasm subcellular localization of connexins [18]. The relation of decreased expression of both Connexin 43 and Ecadherin was associated with a poor differentiation, advanced TNM stage, and lymph node metastasis [18]. The expression decay occurred progressively from normal distant tissue to adjacent tissue and cancer nodules and is related to nodal lung micrometastasis [19]. Connexin 43 expression also correlated with the cancer degree of differentiation. It has been shown that poorly differentiated lung adenocarcinoma and squamous cell carcinoma expressed lower levels than well-differentiated and moderate-differentiated cancers [20]. This aberrant expression could be explained by promoter methylation, probably for AP1 binding, [19].

Higher incidence of lung tumors was initially described by our research group. Heterozygous knockout mice $\mathrm{Cx} 43^{+/-}$ presented statistically more lung papillary adenomas and with a higher number of cells stained for PCNA than wildtype animals. Furthermore, the lesions had larger areas, and these animals presented lower expression or Cx43 mRNA [14]. This experiment used urethane induction, and mice lived only 6 months; maybe the short experiment duration and the different carcinogen used could explain why we found correlation with malignant tumors and not with benign ones.

Another study from our group using NNK for lung carcinogenesis induction corroborates the $\mathrm{Cx} 43^{+/-}$susceptibility 
TABLE 2: Cancer incidence in DMBA wild-type and heterozygote mice induced groups.

\begin{tabular}{|c|c|c|c|c|c|}
\hline Cancer topography & $\begin{array}{l}\text { Heterozygote } \\
\left(\mathrm{Cx} 43^{+/-}\right)\end{array}$ & $\begin{array}{l}\text { Wild-type } \\
\left(\mathrm{Cx} 43^{+/+}\right)\end{array}$ & Odds ratio $(95 \% \mathrm{IC})^{1}$ & Relative risk $(95 \% \mathrm{IC})^{1}$ & $P$ value \\
\hline Mammary gland & 36 & 27 & $\begin{array}{c}1.128 \\
(0.5708-2.230)\end{array}$ & $\begin{array}{c}1.067 \\
(0.7399-1.538)\end{array}$ & 0.7285 \\
\hline Lymphoid tissue & 32 & 26 & $\begin{array}{c}0.9732 \\
(0.4902-1.932)\end{array}$ & $\begin{array}{c}0.9846 \\
(0.6662-1.455)\end{array}$ & 0.9380 \\
\hline Digestive tract & 20 & 16 & $\begin{array}{c}1.000 \\
(0.4640-2.155)\end{array}$ & $\begin{array}{c}1.000 \\
(0.5694-1.756)\end{array}$ & 1.0000 \\
\hline Lung & 21 & 7 & $\begin{array}{c}2.944 \\
(1.155-7.506)\end{array}$ & $\begin{array}{c}2.400 \\
(1.094-5.264)\end{array}$ & $0.0200^{*}$ \\
\hline Skin & 10 & 9 & $\begin{array}{c}0.8718 \\
(0.3296-2.306)\end{array}$ & $\begin{array}{c}0.8889 \\
(0.3859-2.047)\end{array}$ & 0.7820 \\
\hline Ovary & 10 & 3 & $\begin{array}{c}2.923 \\
(0.7664-11.150)\end{array}$ & $\begin{array}{c}2.667 \\
(0.7678-9.262)\end{array}$ & 0.1436 \\
\hline Total & 75 & 60 & - & - & - \\
\hline
\end{tabular}

to spontaneous and induced lung cancer and demonstrates that in the heterozygous mice, nodules were larger and surprising expressing higher levels of Cx43 mRNA [21]. Lung neoplasms, spontaneous, or chemical induced are known to be generated by alveolar type II epithelial cells (APTIIs) [22, 23]. $\mathrm{Cx} 43^{+/-}$animals had a lower cell-to-cell communication capacity and elevated proliferation of APTIIs [22], and the transfection of Gja1 (Cx43 gene) gene in E9 APTII neoplasia cells, in other study, reestablished and rendered these cells to a nonneoplastic state [23]. The role of $\mathrm{Cx} 43$ must be extensively studied for molecular carcinogenesis processes comprehension in the lung.

Another point to highlight is the ovarian cancer occurrence in this experiment. It is known that the connexin 43 is expressed in ovarian tissue, being governed by gonadotropins in transcription, translation, and posttranslational modification. Within their physiological functions, $\mathrm{Cx} 43$ plays a role in the control of follicular genesis and oogenesis and seems to act here as a tumor suppressor gene [24]. According to Fernstrom et al. (2002) [25], gap junction proteins are often reduced in neoplastic cells, including cells of ovarian carcinoma. The same group of researchers conducted an interesting study in vitro to gene therapy, using the $\mathrm{Cx} 43$ directed to ovarian cancer. Transfecting ovarian carcinoma cells with $\mathrm{Cx} 43$ gene decreased cell proliferation and increased sensitivity to adriamycin, suggesting that communication by gap junction and/or Connexin 43 is able to suppress the neoplastic phenotype of ovarian carcinoma cells and its low expression is involved in neoplastic transformation of these cells. Although our observations in this paper have not found statistically significant differences in values between the groups, in absolute numbers, in the group with heterologous deletion of $\mathrm{Cx} 43$, there was a higher incidence of ovarian neoplasms, above twice than manifested in wild group. It is possible that if a larger number of animals were studied, the correlation would demonstrate what strongly corroborate with this role assigned to $\mathrm{Cx} 43$, whose depletion could favor the ovarian carcinogenesis.

\section{Conclusion}

The Cx43 deficient mice predisposition to lung neoplasms had been demonstrated as well as the gap junction role in the carcinogenic process in this organ. Our study strengthens the evidence by DMBA carcinogenic protocol, which is not a lung-specific carcinogen. In addition, the predisposition of ovary granulosa cell carcinoma for Connexin 43 deficiency had a consistent literature basement, and the authors suggest further studies to correlate both in vivo in a more specific carcinogenic model for this kind of tumor.

\section{Acknowledgments}

This work is part of the Ph.D. thesis of Krishna Duro de Oliveira, in the Postgraduation Program in Experimental and Comparative Pathology, School of Veterinary Medicine and Animal Science, University of São Paulo. Marcello Vannucci Tedardi participated in this project as a Scientific Initiation Fellow of Fundação de Amparo a Pesquisa do Estado de São Paulo, FAPESP, proc. 2010/00874-2. The project has also received a financial support from FAPESP, proc. 2010/08480-3.

\section{References}

[1] M. Mesnil, "Connexins and cancer," Biology of the Cell, vol. 94, no. 7-8, pp. 493-500, 2002.

[2] M. Vinken, T. Vanhaecke, P. Papeleu, S. Snykers, T. Henkens, and V. Rogiers, "Connexins and their channels in cell growth and cell death," Cellular Signalling, vol. 18, no. 5, pp. 592-600, 2006.

[3] M. L. Zaidan Dagli and F. J. Hernandez-Blazquez, "Roles of gap junctions and connexins in non-neoplastic pathological processes in which cell proliferation is involved," Journal of Membrane Biology, vol. 218, no. 1-3, pp. 79-91, 2007.

[4] K.-K. Luiza, S. Stanislaw, K. Mariusz, W. Andrzej, R. Tadeusz, and M. Mariola, "The role of connexins in carcinogenesis: 
review of current knowledge," Current Signal Transduction Therapy, vol. 2, no. 1, pp. 49-56, 2007.

[5] D. S. Sanches, C. G. Pires, H. Fukumasu et al., "Expression of connexins in normal and neoplastic canine bone tissue," Veterinary Pathology, vol. 46, no. 5, pp. 846-859, 2009.

[6] R. Kar, N. Batra, M. A. Riquelme, and J. X. Jiang, "Biological role of connexin intercellular channels and hemichannels," Archives of Biochemistry and Biophysics, vol. 524, no. 1, pp. 2-15, 2012.

[7] L. N. Torres, J. M. Matera, C. H. Vasconcellos, J. L. Avanzo, F. J. Hernandez-Blazquez, and M. L. Z. Dagli, "Expression of connexins 26 and 43 in canine hyperplastic and neoplastic mammary glands," Veterinary Pathology, vol. 42, no. 5, pp. 633641, 2005.

[8] J. C. Sáez, V. M. Berthoud, M. C. Brañes, A. D. Martínez, and E. C. Beyer, "Plasma membrane channels formed by connexins: their regulation and functions," Physiological Reviews, vol. 83, no. 4, pp. 1359-1400, 2003.

[9] J. K. Chipman, A. Mally, and G. O. Edwards, "Disruption of gap junctions in toxicity and carcinogenicity," Toxicological Sciences, vol. 71, no. 2, pp. 146-153, 2003.

[10] B. Cogliati, T. C. Da silva, T. P. A. Aloia et al., "Morphological and molecular pathology of CCL4-induced hepatic fibrosis in connexin43-deficient mice," Microscopy Research and Technique, vol. 74, no. 5, pp. 421-429, 2011.

[11] W. R. Loewenstein and Y. Kanno, "Intercellular communication and the control of tissue growth: lack of communication between cancer cells," Nature, vol. 209, no. 5029, pp. 1248-1249, 1966.

[12] M. V. Tedardi, K. D. Oliveira, G. U. Avanzo et al., "Chemical carcinogenesis by 7, 12- dimethylbenzanthracene in BALB/c mice," Annals of the 4th Symposium of the Latin American Society of Toxicologic Pathology, LASTP, http://www.alaptox.net .

[13] A. G. Reaume, P. A. De Sousa, S. Kulkarni et al., "Cardiac malformation in neonatal mice lacking connexin43," Science, vol. 267, no. 5205, pp. 1831-1834, 1995.

[14] J. L. Avanzo, M. Mesnil, F. J. Hernandez-Blazquez et al., "Increased susceptibility to urethane-induced lung tumors in mice with decreased expression of connexin43," Carcinogenesis, vol. 25, no. 10, pp. 1973-1982, 2004.

[15] V. Turusov and U. Mohr, Pathology of Tumours in Laboratory Animals: Tumors of the Mouse, IARC Scientific Publication (WHO), Lyon, France, 2nd edition, 1994.

[16] K. Yamakage, Y. Omori, C. Piccoli, and H. Yamasaki, "Growth control of 3T3 fibroblast cell lines established from connexin 43deficient mice," Molecular Carcinogenesis, vol. 23, pp. 121-128, 1998.

[17] K. Cesen-Cummings, M. J. Fernstrom, A. M. Malkinson, and R. J. Ruch, "Frequent reduction of gap junctional intercellular communication and connexin43 expression in human and mouse lung carcinoma cells," Carcinogenesis, vol. 19, no. 1, pp. 61-67, 1998.

[18] H.-T. Xu, Q.-C. Li, Y.-X. Zhang et al., "Connexin 43 recruits Ecadherin expression and inhibits the malignant behaviour of lung cancer cells," Folia Histochemica et Cytobiologica, vol. 46, no. 3, pp. 315-321, 2008.

[19] J.-T. Chen, Y.-W. Cheng, M.-C. Chou et al., "The correlation between aberrant connexin 43 mRNA expression induced by promoter methylation and nodal micrometastasis in non-small cell lung cancer," Clinical Cancer Research, vol. 9, no. 11, pp. 4200-4204, 2003.
[20] Y. Jinn, M. Ichioka, and F. Marumo, "Expression of connexin32 and connexin43 gap junction proteins and E-cadherin in human lung cancer," Cancer Letters, vol. 127, no. 1-2, pp. 161-169, 1998.

[21] H. Fukumasu, J. L. Avanzo, D. S. Sanches, G. Mennecier, C. M. C. Mori, and M. L. Z. Dagli, "Higher susceptibility of spontaneous and NNK-induced lung neoplasms in connexin 43 deficient $\mathrm{CD} 1 \times \mathrm{AJ}$ F1 mice: paradoxical expression of connexin 43 during lung carcinogenesis," Molecular Carcinogenesis, vol. 52, no. 7, pp. 497-506, 2013.

[22] J. L. Avanzo, G. Mennecier, M. Mesnil et al., "Deletion of a single allele of $\mathrm{Cx} 43$ is associated with a reduction in the gap junctional intercellular communication and increased cell proliferation of mouse lung pneumocytes type II," Cell Proliferation, vol. 40, no. 3, pp. 411-421, 2007.

[23] K. A. Peebles, M. W. Duncan, R. J. Ruch, and A. M. Malkinson, "Proteomic analysis of a neoplastic mouse lung epithelial cell line whose tumorigenicity has been abrogated by transfection with the gap junction structural gene for connexin 43, Gjal," Carcinogenesis, vol. 24, no. 4, pp. 651-657, 2003.

[24] E. Gershon, V. Plaks, and N. Dekel, "Gap junctions in the ovary: expression, localization and function," Molecular and Cellular Endocrinology, vol. 282, no. 1-2, pp. 18-25, 2008.

[25] M. J. Fernstrom, L. D. Koffler, G. Abou-Rjaily, P. D. Boucher, D. S. Shewach, and R. J. Ruch, "Neoplastic reversal of human ovarian carcinoma cells transfected with Connexin43," Experimental and Molecular Pathology, vol. 73, no. 1, pp. 54-60, 2002. 


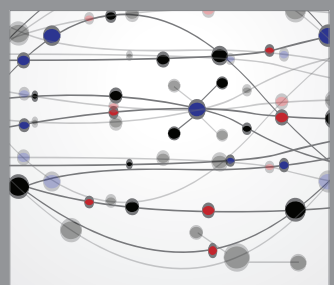

The Scientific World Journal
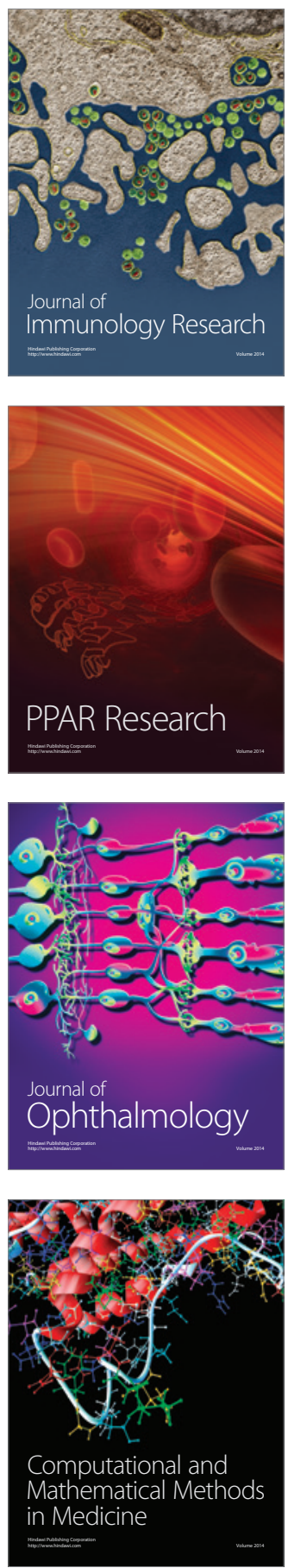

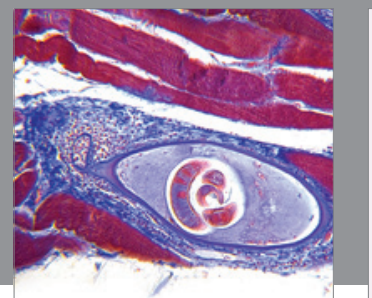

Gastroenterology

Research and Practice
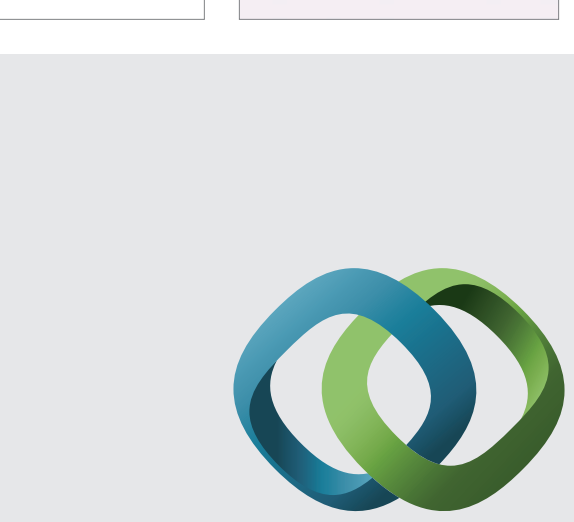

\section{Hindawi}

Submit your manuscripts at

http://www.hindawi.com
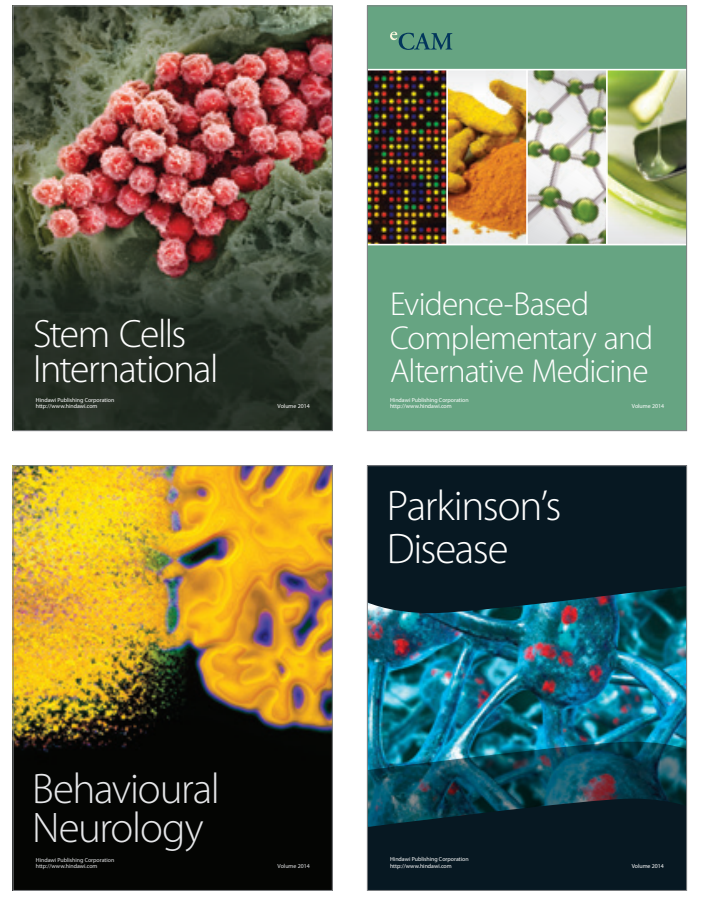
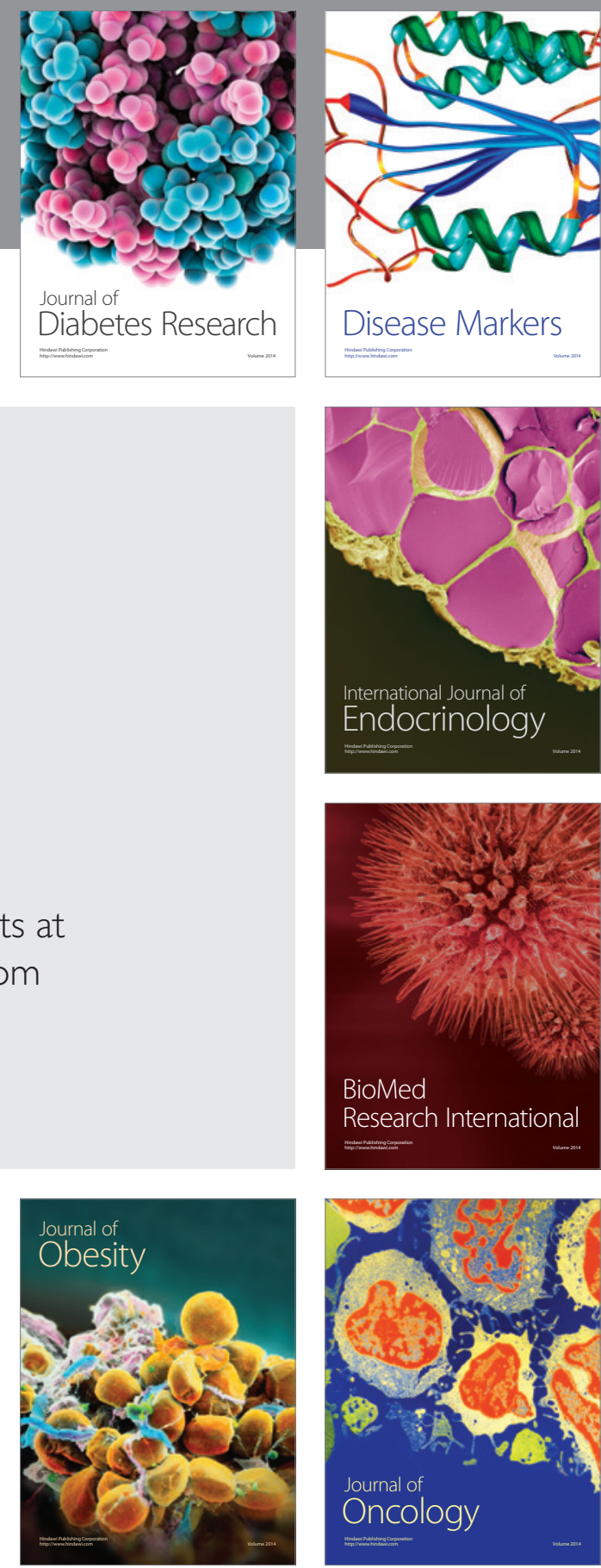

Disease Markers
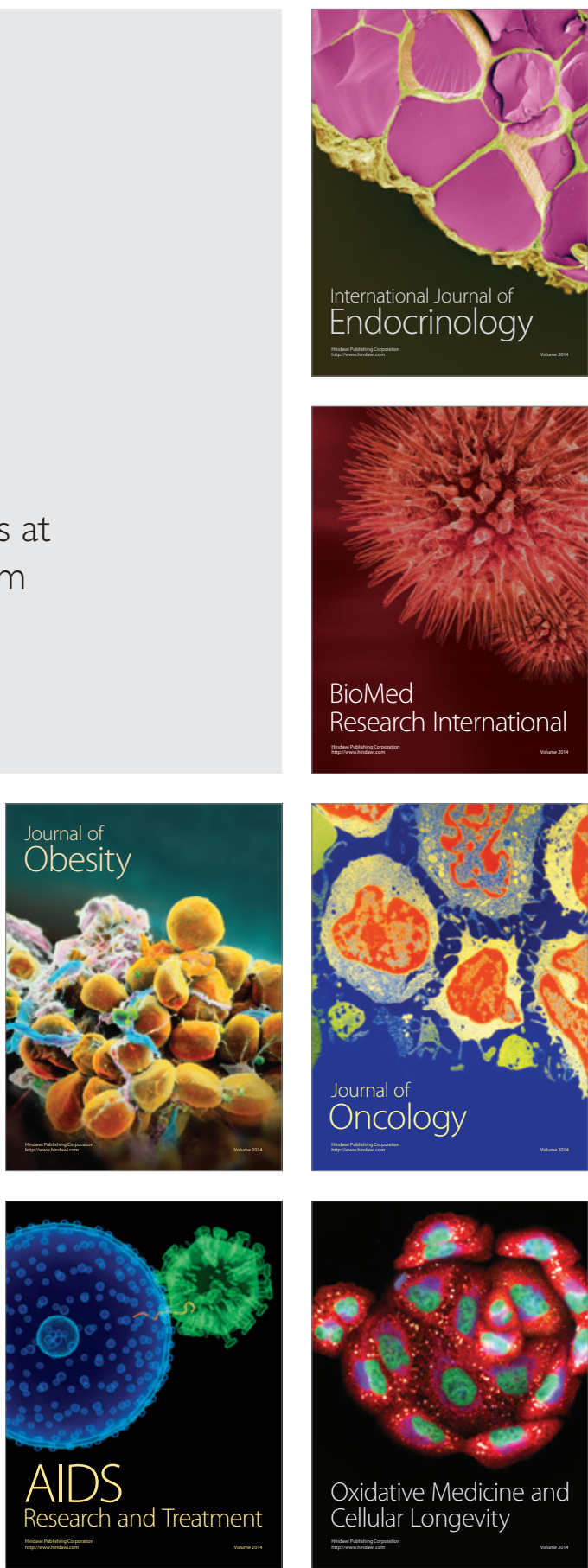